\title{
Climate Change and Anthropogenic Impact Around the Korean Coastal Ecosystems: Korean Long-term Marine Ecological Research (K-LTMER)
}

\author{
Jung-Ho Hyun ${ }^{1}$ (D) $\cdot{\text { Kwang-Sik } \text { Choi }^{2} \cdot K \text { Kun-Seop Lee }}^{3} \cdot$ Sang Heon Lee $^{4} \cdot$ Young Kyun Kim $^{5} \cdot$ Chang-Keun Kang $^{5}$
}

Received: 24 January 2020 / Revised: 27 January 2020 / Accepted: 30 January 2020 / Published online: 11 February 2020

(C) Coastal and Estuarine Research Federation 2020

\section{Background}

The East-Asian Marginal Seas (EAMS), including the Yellow Sea, the East China Sea, and the East Sea (Fig. 1), are regarded as one of the hot spots where rapid warming of seawater occurs. During the period from 1982 to 2006, sea surface temperature (SST) of the EAMS increased $0.67-1.09{ }^{\circ} \mathrm{C}$, which is the highest among the 18 large marine ecosystems (LME) in the world (Belkin 2009), and is 2-4 times higher than the global SST warming rate of $0.13^{\circ} \mathrm{C}$ per decade (IPCC 2007). The climate change-induced variations in physical oceanographic conditions have greatly altered the composition, abundance, and metabolic activities of lower trophic levels (i.e., heterotrophic bacteria, phytoplankton, and zooplankton) as well as the seasonal peak abundance of phytoplankton in the East Sea and Yellow Sea (Chiba and Saino 2003; Chiba et al. 2012; Jahan et al. 2013; Jahan and Choi

Communicated by Charles Simenstad

Jung-Ho Hyun

hyunjh@hanyang.ac.kr

1 Department of Marine Science and Convergent Technology, Hanyang University, 55 Hanyangdaehak-ro, Ansan, Gyeonggi-do 15588, Korea

2 School of Marine Biomedical Science, Jeju National University, 102 Jejudaehak-ro, JeJu 63243, Korea

3 Department of Biological Sciences, Pusan National University, 2 Busandaehak-ro, Busan 46241, Korea

4 Department of Oceanography, Pusan National University, 2 Busandaehak-ro, Busan 46241, Korea

5 School of Earth Sciences and Environmental Engineering, Gwangju Institute of Science and Technology, 123 Cheomdangwagi-ro, Gwangju 61005, Korea
2014; Joo et al. 2014; Lee et al. 2014; Jung et al. 2017; Kim et al. 2017b; Kim et al. 2019a; Park et al. 2019f). In addition to climatic change, intense anthropogenic activities, including reclamation of coastal wetlands, construction of artificial dikes along the coasts and at the river mouth, and intense aquaculture operation, have exerted profound effects on the physico-chemical and biological conditions in this region (Jahan et al. 2013; Sin et al. 2013, 2015; Kim et al. 2017c; An et al. 2019; Choi et al. 2020).

Coastal upwelling is one of the unique physical oceanographic properties along the southeast Korean peninsula and is largely responsible for the high primary production of the Ulleung Basin (UB) in the East Sea (Hyun et al. 2009; Yoo and Park 2009). However, the strength of southwesterly wind stimulating the upwelling has decreased by up to $34 \%$ in the 2000s compared with the 1960s (KORDI 2010), and the SST has increased $1.09{ }^{\circ} \mathrm{C}$ during the period of 1982-2006 in the East Sea including the UB (Belkin 2009). The weakened wind strength and warming of seawater may induce a relatively stronger stratification (i.e., pycnocline) at the surface mixed layer, which ultimately lower upward flux of major nutrients (Sarmiento et al. 1998). Nutrient depletion in the mixed layer of the UB resulted in a shift of phytoplankton size distribution from large diatoms to smaller flagellates, and consequently annual primary production has decreased $\sim 17 \%$ (approximately $50 \mathrm{~g} \mathrm{C} \mathrm{m}^{-2}$ year $^{-1}$ ) since 2006 (Joo et al. 2014). Since small phytoplankton have lower sinking rates than large phytoplankton (Legendre and Le Fèvre 1995; Winder and Sommer 2012; Siegel et al. 2014), a higher contribution of small phytoplankton can cause lower export production in the UB (Kim et al. 2017b).

In the Gyeonggi Bay of the Yellow Sea, due to the early winter warming, the spring diatom blooms observed in the 1990s moved forward to winter blooms in the 2000s (Jahan and Choi 2014). In addition, as the wind stress weakens in 
Fig. 1 Major research sites for Korean Long-Term Marine Research (K-LTMER) program around the Korean peninsula

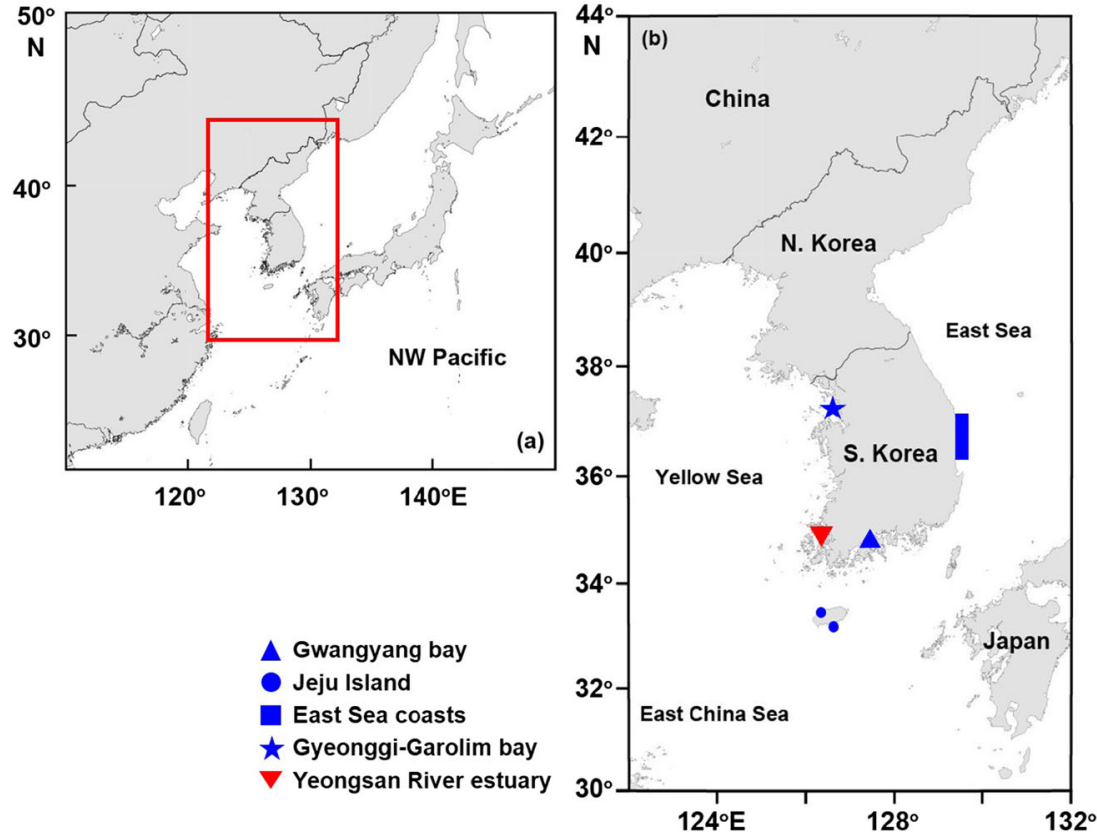

winter, turbulent water mixing has decreased in this shallow coastal bay, and Thalassiosira nordenskioeldii (planktonic diatom) has become the only dominant species during winter blooms since 1998, while Paralia sulcata (tychopelagic or benthic diatom) was the most dominant species during 1981-1982 (Jahan et al. 2013). These climate-driven changes in the phytoplankton community may have cascading ecosystem effects, thereby affecting the composition, abundance, and community structures of the higher trophic levels in the EAMS (Joo et al. 2017; Jung et al. 2017).

As a result of the warmer SST, Halophila nipponica (seagrass), which is reported generally in warm temperate Japanese waters (Kuo et al. 2006), has been observed in the southern coastal waters of Korea (Kim et al. 2009; Kim et al. 2012; Kim et al. 2017a) where cold affinity Zosteria marina is typically the dominant native seagrass species (Lee and Lee 2003; Lee et al. 2005). Similarly, recent appearance of the Spartina spp. (saltmarsh plant) in the intertidal sediments of the Yellow Sea where Suaeda japonica is the dominating native salt marsh plant (An et al. 2020) was largely ascribed to climate change-induced warming. Inhabitation of these invasive plants significantly modify the biogeochemical cycles of $\mathrm{C}, \mathrm{N}, \mathrm{P}, \mathrm{Fe}$, and $\mathrm{S}$ and microbial communities in the sediments (Kim et al. 2017a; An et al. 2020).

An enhanced anthropogenic carbon input is to be largely responsible for both $\mathrm{pCO}_{2}$ increase and ocean acidification in the East Sea. During the period from 1995 to 2009, studies in the East Sea reported increasing $\mathrm{fCO}_{2}$ in surface sea water $\left(2.7 \pm 1.1 \mu\right.$ atm year $\left.^{-1}\right)$ and $\mathrm{pH}$ levels $(-0.03 \pm 0.02 \mathrm{pH}$ units per decade) that were higher than observations at most other ocean time-series sites during the same period (Kim et al. 2014b). Similarly, increasing anthropogenic N deposition was ascribed to the enhanced reactive $\mathrm{N}$ in the surface mixed layer of the EAMS (Kim et al. 2011; Kim et al. 2014a), implying an ecological transition from N-limited to P-limited condition.

Coastal wetlands protect coastal regions from storms and sea-level rise, transform organic matter, metals and nutrients, and provide nursery grounds that support commercial fisheries (Barbier et al. 2011; Kirwan and Megonigal 2013; Mok et al. 2019; Neubauer and Verhoeven 2019). Tidal marsh ecosystems are considered the most efficient natural organic carbon sinks on earth, and thus coastal reclamation to expand land use could result in increased emissions of greenhouse gases $\left(\mathrm{CO}_{2}, \mathrm{CH}_{4}\right.$, and $\left.\mathrm{N}_{2} \mathrm{O}\right)$, which further affects local/ global carbon cycles (Li et al. 2014; Ewers Lewis et al. 2019). Remote-sensing analysis along the Yellow Sea coastline, including China, North Korea, and South Korea, revealed that $28 \%$ of tidal flats existing in the 1980s had disappeared by the late 2000s (1.2\% annually) (Murray et al. 2014). Yim et al. (2018) also reported that the area of tidal flats in the Yellow Sea had been reduced by $36 \%$ in the 2010s $\left(\sim 6670 \mathrm{~km}^{2}\right)$ compared with the $1980 \mathrm{~s}\left(\sim 10,500 \mathrm{~km}^{2}\right)$. The area of coastal reclamation in South Korea during this period was $2360 \mathrm{~km}^{2}$ (Yim et al. 2018).

Large-scale coastal reclamation and land-use projects in South Korea were inevitably accompanied by the construction of enormous artificial seawalls, such as the Yeongsan River Dike (4.35 km long), Shihwa Dike (12.7 km long), and Saemangeum Dike (33.9 km long), which is the longest seawall in the world (Choi 2014; Yim et al. 2018). Construction of the dike in the Yeongsan River estuary led to a marked 
increase in the tidal amplitude and a decrease in the current velocity (Kang 1999), which ultimately resulted in the accumulation of organic matter in the sediments near the dikes (Kim et al. 2017c; An et al. 2019). A similar situation associated with the massive accumulation of organic material on coastal sediment applies to the aquaculture activities in coastal environments (Dempster and Holmer 2009). Aquaculture production in Korea was ranked 7th among the world's top 25 aquaculture countries in 2014 (FAO 2018) and accounted for $62 \%$ of total seafood production (3.72 million tonnes) in 2017 (KOSIS 2018). In organic-rich coastal sediments, $\mathrm{O}_{2}$ is rapidly depleted within a few millimeters depth of the surface sediment, and most organic carbon oxidation is carried out by anaerobic respiration processes, mostly by sulfate reduction due to high abundance of $\mathrm{SO}_{4}{ }^{2-}$ in seawater (Canfield et al. 2005; Jørgensen 2006). Major environmental concerns associated with the dominance of organic carbon oxidation by sulfate reduction include the accumulation of highly toxic and reactive hydrogen sulfide $\left(\mathrm{H}_{2} \mathrm{~S}\right)$ (Holmer et al. 2005; Hyun et al. 2013; Kim et al. 2017c).

In the estuarine sediments near the Yeongsan River Dike, sulfate reduction accounted for $73 \%$ of organic carbon oxidation and was responsible for strikingly high concentrations of the $\mathrm{H}_{2} \mathrm{~S}(487 \mu \mathrm{M})$ in the pore water (Kim et al. $2017 \mathrm{c}$ ). Similarly, sulfate reduction accounted for $48-99 \%$ (average $70 \%$ ) of the total organic carbon oxidation in the sediment of an oyster farm (Hyun et al. 2013). The $\mathrm{H}_{2} \mathrm{~S}$ produced from the sulfate reduction reacts quickly with iron oxides to form iron sulfides, which ultimately releases the $\mathrm{P}$ bound to $\mathrm{Fe}$ (III) into the pore water, thereby enhancing the benthic $\mathrm{P}$ flux near the dike (An et al. 2019). Finally, the enhanced benthic nutrient flux may contribute to coastal eutrophication, which may stimulate primary production in the water column via benthicpelagic coupling in shallow coastal ecosystems. Recently, Choi et al. (2020) estimated that the benthic nutrient release from fish farm sediment accounted for $52-837 \%$ and $926-$ $1048 \%$, respectively, of the $\mathrm{N}$ and $\mathrm{P}$ demand for phytoplankton production in the southern coast of Korea. Similarly, Kim et al. (2017c) also reported that the benthic nutrient flux at the sediment near the Yeongsan River Dike accounted for $200 \%$ of $\mathrm{N}$ and $\mathrm{P}$, respectively, required for primary production in the water column.

The enhanced nutrient conditions (i.e., eutrophication) resulting from the anthropogenic activities in the coastal ecosystem are also responsible for the incidence of harmful algal blooms (HABs) that have been increasing continuously for decades around the world (Hallegraeff 1993; Heisler et al. 2008). In Korea, Cochlodinium polykrikoides is the dominant species causing major economic losses such as massive mortality of aquaculture and wild fishes or shellfishes (Lee et al. 2013). The economic loss by the C. polykrikoides bloom in Korea reached USD \$7 million in 1993, USD \$60 million in 1995, and ranged from 4 to USD $\$ 19$ million per year from
2000 to 2012 (see Shin et al. 2017). The eutrophication and resulting algal bloom make environmental conditions even worse by developing a hypoxia ( $\mathrm{DO} \leq 2 \mathrm{mg} \mathrm{L}^{-1}$ ) that is responsible for the unexpected changes in biogeochemical element cycles and ecosystem structures (Conley et al. 2002, 2009; Diaz and Rosenberg 2008; Middelburg and Levin 2009; Rabalais et al. 2010). In Korea, intense anthropogenic activities such as reclamation, construction of artificial structures (i.e., dikes), and aquaculture activities, have been mostly responsible for the continuously growing incidence of coastal eutrophication and hypoxia (Lee and Kim 2008; Lim et al. 2012; Kim et al. 2015; see Lee et al. 2018).

\section{Scope and Objectives of the K-LTMER}

These climatic changes and anthropogenic activities have resulted in a series of interrelated environmental issues, which ultimately alter the ecological and biogeochemical processes of the estuarine and coastal ecosystems of Korea. Therefore, understanding the current status of ecosystem structure and elucidating cause-effect relationships to changes in major ecological and biogeochemical processes become imperative not only to evaluate/predict the ecosystem changes associated with climatic changes and anthropogenic activities, but also to provide relevant scientific information that should be considered by decision makers for maintenance of sustainable estuarine and coastal environments.

In this respect, the Korean Long-Term Marine Ecological Research (K-LTMER) program under the auspices of Korean Ministry of Oceans and Fisheries has been carrying out ecological and biogeochemical process studies for the last 10 years since 2010 :

1. To obtain environmental baseline information including monitoring of indicator organisms and their physicochemical controls under current status;

2. To diagnose/evaluate short-term response in ecological processes to the recent climatic regime shift in late 1990s and catastrophic anthropogenic events occurred in the last 10-20 years;

3. To predict long-term changes and response of marine ecosystems associated with large-scale anthropogenic activities and rapidly changing climatic conditions around the Korean peninsula.

Ecological monitoring studies on various indicator biological communities include prokaryotes, eukaryotic microplankton, macrofauna, seagrasses and fishes, and the measurements of physico-chemical and geochemical parameters that ultimately determine the shape and shift of the biological communities. Ecological and biogeochemical process studies include metabolic rate measurements such as phytoplankton 
primary production, bacteria secondary production, microbial respiration, and benthic mineralization of organic matter coupled with functional analysis of biological communities using metagenomic and metatranscriptomic approaches. The study area was divided into four coastal regions that represent the unique environmental features around the Korean peninsula (Fig. 1b):

1. Estuarine and coastal waters in the Gwangyang Bay along the riverine-estuarine-coastal marine continuum in the southern part of the Korean peninsula;

2. Intertidal wetlands and coastal waters in the GarolimGyeonggi Bay in the eastern part of the Yellow Sea (i.e., western part of the Korean peninsula);

3. Subtropical coastal ecosystem in Jeju Island near the East China Sea; and,

4. Coastal upwelling ecosystem in the Ulleung Basin of the East Sea.

\section{Overview of the Special Issue}

Whereas another previous special issue of the K-LTMER mostly dealt with the current status of the East Sea in changing environmental conditions earlier (Lee et al. 2017), in this special issue, we present 16 papers that address a broad range of topics covered mostly in the estuarine and coastal ecosystems of the four major K-LTMER sites and the Yeongsan River estuary where a large artificial dike (i.e., Yeongsan River Dike) has exerted a profound impact on coastal and estuarine ecosystems (Kim et al. 2017c; An et al. 2019; Sin and Jeong 2019; Park et al. 2019b; Fig. 1).

The greater part of this special issue features ecological and biogeochemical baseline studies that will provide relevant information to evaluate and predict the variations of ecosystems in response to the long-term climate changes and anthropogenic impacts.

Qin et al. (2019) investigated the reproductive phenology and sexual reproduction of Zostera marina in two seagrass sites to elucidate the response of native cold affinity seagrass (Z. marina) to warming of seawater. They demonstrated that cold water upwelling in the east coast provided a relatively long period of optimal water temperature for production of $Z$. marina, leading to a prolonged flowering period and enhanced seed production. By contrast, high summer water temperature appeared to shorten the flowering period and reduce sexual reproduction of $Z$. marina in the south coast sites. Kim et al. (2019c) also found that the growth of $Z$. marina under anomalously elevated water temperature conditions was significantly declined, whereas the plant growth was maintained or slightly increased under suddenly decreased water temperature conditions. The results suggested that intensified sea surface water temperature anomalies induced by global climate change will alter the growth and distribution of temperate seagrasses, thereby affecting the long-term stability and maintenance of seagrass meadows.

In contrast to the clear response of Zostera to warming (Kim et al. 2019c; Qin et al. 2019), Park et al. (2019e) found the that the small SST difference between 20 and $25^{\circ} \mathrm{C}$ in Jeju Island had no significant influence on reproductive physiology of Alveopora japonica and Oulastrea crispate, the two high-latitude corals. The results suggest that although recent expansion and explosion of the A. japonica population from the south into the north of the Island might be linked to the increase in SST in the East China Sea, this needs to be substantiated through long-term monitoring of patterns of coral reproduction and population dynamics. As a part of the environmental baseline study in the Jeju Island site, Kwon et al. (2018) elucidated that southern coastal waters (SCW) off Jeju were characterized by higher nutrients and humiclike fluorescent dissolved organic matter $\left(\mathrm{FDOM}_{\mathrm{H}}\right)$, while those in the western coastal waters off Jeju (WCW) showed no trend. Based on a significant negative correlation of salinity against ${ }^{222} \mathrm{Rn}$ activities, the main source of nutrients and $\mathrm{FDOM}_{\mathrm{H}}$ is found to be from fresh groundwater in the SCW. However, depleted ${ }^{222} \mathrm{Rn}$ activities in the fresh surface waters of the WCW indicate that those in the WCW originate mainly from the remote Changjiang diluted water. The results suggested that high nutrient concentrations in the SCW provide favorable conditions for the growth of seaweeds, while relatively low nutrient concentrations and high $\mathrm{FDOM}_{\mathrm{H}}$ concentrations in the WCW provide favorable conditions for survival of corals.

Kim et al. (2019b), using a data from the $\mathrm{C}$ and $\mathrm{N}$ stable isotope analysis, conducted ecological baseline studies on the trophic links of macrobenthic food web in diverse wetland habitats along the riverine-estuarine-coastal marine continuum in low turbidity Gwangyang Bay. They revealed that Phragmites-derived organic matter contributed considerably to the nutrition in the estuarine channel, whereas microphytobenthos and Zostera provided trophic subsidies to the deep bay and offshore communities. On the other hand, Kwak and Cho (2019) revealed that mean residence time in Gwangyang Bay is more than 20 days in winter due to its large volume, but less than 5 days in summer due to increased gravitational circulation driven by large volumes of river discharge and a horizontal density gradient. Both results of Kim et al. (2019b) and Kwan and Cho (2019) imply that food web structure of the benthic macrofauna in the Gwangyang Bay is susceptible to anthropogenic activityinduced topographic changes in the future. Kwak and Cho (2019) additionally reported that the mean residence time of Jinju Bay is less than 5 days in winter and summer due to its small volume and shallow depth, suggesting that the Jinju Bay is likely to remain free from anthropogenic eutrophication 
caused by nutrient inputs from aquaculture throughout the year. As a part of physical oceanographic baseline study, Cho et al. (2019) further measured the circulation pattern of the Sumjin River estuary in the Gwangyang Bay to evaluate the net exchange potential of material in the estuary. They elucidated that the most important factor affecting exchange flow is the horizontal salinity gradient which increases up to 7 times during the spring tide compared with the neap tide. Finally, Kim et al. (2019a) investigated phytoplankton primary production, heterotrophic bacterial production and respiration to evaluate the changes in ecological processes in response to the recent climatic regime shift in late 1990s in Gyeonggi Bay (GB). In comparison with the early 1990s, they found that warming in GB intensified the carbon flux through the microbial loop, which may reduce the efficiency of energy transfer to higher trophic levels.

In addition to the papers providing ecological and environmental baseline information, from the four K-LTMER sites, we invited additional papers dealing with the environmental impacts of large-scale artificial dike in the Yeongsan River estuary (Fig. 1b) and Shihwa Dike in the Gyeonggi Bay (Sin and Jeong 2019; Park et al. 2019b; Kim and Kim 2018), benthic biogeochemistry associated with finfish and shellfish aquaculture (Kim et al. 2019d), and recovery of Manila clam from the catastrophic oil spill off western part of Korea (Park et al. 2019a).

Sin and Jeong (2019) explored semidiurnal and fortnight tidal variations of phytoplankton community (size and taxonomic groups) in the macrotidal Yeongsan River estuary that receives freshwater regulated by the Yeongsan River Dike. Their results revealed that taxonomic variation is associated with freshwater discharge and was explained principally by water temperature and salinity, rather than tidal height. The results imply that episodic anthropogenic freshwater discharge events disturb predictable macrotidal effects on water column processes, thereby enhancing the ecological complexity of estuaries. Tidal interactions with regulated freshwater discharge into estuaries would provide fundamental information on the dynamics of phytoplankton in estuarine ecosystems that are affected by the artificial dikes. Park et al. (2019b) also investigated the modification of carbon flow by a dike construction in estuarine system by making comparisons of the $\delta^{13} \mathrm{C}$ and $\delta^{15} \mathrm{~N}$ values of subtidal macrobenthic consumers in the Yeongsan River estuary affected by the Yeongsan River Dike and the Gwangyang Bay without a dike. They found that the consumer $\delta^{13} \mathrm{C}$ values recorded non-significant spatial differences among sites in the diked estuary, and the isotopic niche widths were much narrower than those in the dike-free estuary. Moreover, the indices of community-wide metrics were smaller in the diked estuary than in the dike-free estuary. These comparisons provide evidence that dike construction and subsequent alteration of hydrologic and circulation processes may lead to modification of the trophic structure of estuarine macrobenthic communities.

Kim and Kim (2018) measured the fluorescence intensity of humic-like fluorescent dissolved organic matter $\left(\mathrm{FDOM}_{\mathrm{H}}\right)$ in brackish Lake Shihwa, the impounded water by the Shihwa Dike. Based on the significantly positive relationship between the fluorescent intensity of $\mathrm{FDOM}_{\mathrm{H}}$ and nutrients $\mathrm{NH}_{4}{ }^{+}$and $\mathrm{PO}_{4}{ }^{3-}$ ) together with the low DO level, they concluded that the enhanced $\mathrm{FDOM}_{\mathrm{H}}$ is released from the anoxic pore water of the sediment. The results indicate that the contribution of $\mathrm{FDOM}_{\mathrm{H}}$ from reducing environments is comparable with that from stream water that is known to be a major source in coastal regions.

Kim et al. (2019d), using an in situ benthic chamber, measured sediment oxygen demand (SOD) and benthic nutrient fluxes to assess the impact of finfish and shellfish (oyster) aquaculture on coastal ecosystems. They consistently found that the SODs at the finfish and oyster farm were more than twice those of the control site. The benthic fluxes of ammonium and phosphate at the finfish and oyster farm were up to 10 times and 7 times, respectively, higher than those of the control site. The results confirm previous reports that the discharge of organic matter from both the commercial finfish and oyster farms enhanced benthic metabolism, locally altering the cycling of organic matter and nutrients in the coastal environments (Hyun et al. 2013; Choi et al. 2020).

Park et al. (2019a) addressed the impact of the Hebei Spirit oil spill, that spread $40 \mathrm{~km}$ to the northeast and $50 \mathrm{~km}$ to the southeast from the collision spot, $10 \mathrm{~km}$ off Taean in the west coast of Korea, on the phenology of Manila clam (Ruditapes philippinarum). Eighteen months after the oil spill, no clear seasonal fluctuations were detected in the biometric components of the clams at the oil-damaged beach, compared with the pronounced seasonal dynamics at the undamaged beach. However, the lack of energy reserves in the clams in the damaged area likely resulted in a failure of gametogenic development because the gross egg weight was much higher at the control than at the damaged site during June-July, emphasizing a 1-month lag in the major spawning pulse at the damaged site. The results suggest that the oil spill may interfere with the clam phenology at Malipo Beach within 2-3 years after the incident.

Finally, the remaining three papers address the dynamics of fish communities in the east coast (Park et al. 2019f) and short-term and long-term variations in phytoplankton distribution using satellite images in the East Sea (Park et al. 2019c, d).

Park et al. (2019f), based on the community composition and stable carbon and nitrogen isotope ratios, reported the temporal variability in the trophic structure of a fish community and the trophic levels of dominant fish species off the eastern coast of Korea. Major findings were that (1) fish assemblages were mainly dominated by resident benthic and 
benthopelagic fish, (2) resident species showed no seasonal differences in their isotopic signatures, whereas pelagic species showed temporal variability in $\delta^{13} \mathrm{C}$ and $\delta^{15} \mathrm{~N}$ values, and (3) the isotopic niche of fish assemblages showed distinctly different patterns between spring-summer and winter-fall with the seasonal changes in the fish community. These patterns might be associated with seasonal variation in fish communities affected by seasonal changes in environmental conditions (e.g., hydrographic parameters and food availability). Park et al. (2019c) produced level-3 chlorophyll-a (chl-a) monthly map in the East Sea from 2003 to 2015. They found a strong contrast in spatial amplitude between the eastern and western areas of the East Sea in March or April, and prominently strong variability in the eastern area along the Japanese coast. The annual peak appeared mainly in March recently, which is 1 month earlier than in the past. The spring bloom of chl-a preferred strong wind as precondition in the early spring. Increasing long-term trend of chl-a concentration had positive relation with shoaling upper layer affected by global warming. Park et al. (2019d) also presented short-term biological responses to sea surface wind field over mesoscale eddies using GOCI (Geostationary Ocean Color Imager) chl-a concentration in the East Sea. In this study, wind field modification over the warm eddies was observed and Ekman pumping (EKP) velocity field was derived from the scatterometer wind data. Their results demonstrated that the biological response to the eddy-/wind-induced EKP arouses very quickly on an hourly base. They also revealed that the SST-induced EKP played a significant role in total EKP by air-sea interaction because of a subpolar front in the central East Sea over the anticyclonic eddies.

Acknowledgments The authors thank Co-Editors-in-Chief, Professors Charles Simenstad and Paul Montagna, of the ESCO for their dedicated editorial service for this special issue.

Funding information This research was supported by the Korean LongTerm Marine Ecosystem Research (K-LTMER) program funded by the Korean Ministry of Oceans and Fisheries.

\section{References}

An, S.-U., J.-S. Mok, S.-H. Kim, J.-H. Choi, and J.-H. Hyun. 2019. A large artificial dyke greatly alters partitioning of sulfate and iron reduction and resultant phosphorus dynamics in sediments of the Yeongsan River estuary, Yellow Sea. Science of the Total Environment 665: 752-761.

An, S.-U., H. Cho, U.-J. Jung, B. Kim, H. Lee, C.-K. Kang, and J.-H. Hyun. 2020. Invasive Spartina anglica greatly alters the rates and pathways of organic carbon oxidation and associated microbial communities in an intertidal wetland of the Han River Estuary, Yellow Sea. Frontiers in Marine Science (in press).

Barbier, E.B, S.D. Hacker, C. Kennedy, E.W. Koch, A.C. Stier, and B.R. Silliman. 2011. The value of estuarine and coastal ecosystem services. Ecological Monographs 81: 169-193.
Belkin, I.M. 2009. Rapid warming of large marine ecosystems. Progress in Oceanography 81: 207-213.

Canfield, D.E., B. Thamdrup, and E. Kristensen. 2005. Aquatic geomicrobiology. San Diago: Elsevier Academic Press.

Chiba, S., and T. Saino. 2003. Variation in mesozooplankton community structure in the Japan/East Sea (1991-1999) with possible influence of the ENSO scale climatic variability. Progress in Oceanography 57: 317-339.

Chiba, S., S. Batten, K. Sasaoka, Y. Sasai, and H. Sugisaki. 2012. Influence of the Pacific decadal oscillation on phytoplankton phenology and community structure in the western North Pacific. Geophysical Research Letters 39: L15603. https://doi.org/10.1029/ 2012GL052912.

Cho, E.-B., Y.-K. Cho, and J. Kim. 2019. Enhanced exchange flow during spring tide and its cause in the Sumjin River estuary, Korea. Estuaries and Coasts https://oi.org/10.1007/s12237-019-00636-9.

Choi, Y.R. 2014. Modernization, development and underdevelopment: Reclamation of Korean tidal flats, 1950s-2000s. Ocean \& Coastal Management 102: 426-436.

Choi, A., B. Kim, J.-S. Mok, J. Yoo, J.B. Kim, W.-C. Lee, and J.-H. Hyun. 2020. Impact of finfish aquaculture on biogeochemical processes in coastal ecosystems and elemental sulfur as a relevant proxy for assessing farming condition. Marine Pollution Bulletin 150: 110635. https://doi.org/10.1016/j.marpolbul.2019.110635.

Conley, D.J., C. Humborg, L. Rahm, O.P. Savchuk, and F. Wulff. 2002. Hypoxia in the Baltic Sea and basin-scale changes in phosphorus biogeochemistry. Environmental Science and Technology 36 (24): 5315-5320. https://doi.org/10.1021/es025763w.

Conley, D.J., J. Carstensen, R. Vaquer-Sunyer, and C.M. Duarte. 2009. Ecosystem thresholds with hypoxia. Hydrobiologia 629: 21-29. https://doi.org/10.1007/s10750-009-9764-2.

Dempster, T., and M. Holmer. 2009. Introducing the new multidisciplinary journal Aquaculture Environment Interactions. Aquaculture Environment Interaction 1: i-ii.

Diaz, R.J., and R. Rosenberg. 2008. Spreading dead zones and consequences for marine ecosystems. Science 321 (5891): 926-929.

Ewers Lewis, C.J., J.A. Baldock, B. Hawke, P.S. Gaddc, A. Zawadzki, H. Heijnis, G.E. Jacobsen, K. Rogers, and P.I. Macreadie. 2019. Impacts of land reclamation on tidal marsh 'blue carbon' stocks. Science of the Total Environment 672: 427-437.

FAO. 2018. The state of world fisheries and aquaculture: Meeting the sustainable development goals. Rome: The Food and Agriculture Organization of the United Nations.

Hallegraeff, G.M. 1993. A review of harmful algal blooms and their apparent global increase. Phycologia 32: 79-99.

Heisler, J., P.M. Glibert, J.M. Burkholder, D.M. Anderson, W. Cochlan, W.C. Dennison, Q. Dortch, C.J. Gobler, C.A. Heil, E. Humphries, A. Lewitus, R. Magnien, H.G. Marshall, K. Sellner, D.A. Stockwell, D.K. Stoecker, and M. Suddleson. 2008. Eutrophication and harmful algal blooms: A scientific consensus. Harmful Algae 8 (1): 3-13.

Holmer, M., D. Wildish, and B. Hargrave. 2005. Organic enrichment from marine finfish aquaculture and effects on sediment biogeochemical processes. The Handbook of Environmental Chemistry 5: 181-206.

Hyun, J.-H., D. Kim, C.-W. Shin, J.-H. Noh, E.-J. Yang, J.-S. Mok, S.-H. Kim, H.C. Kim, and C. Yoo. 2009. Enhanced phytoplankton and bacterioplankton production coupled to coastal upwelling and an anticyclonic eddy in the Ulleung basin, East Sea. Aquatic Microbial Ecology 54: 45-54.

Hyun, J.-H., S.-H. Kim, J.-S. Mok, J.S. Lee, S.-U. An, W.C. Lee, and R.H. Jung. 2013. Impact of long-line aquaculture of Pacific oysters (Crassostrea gigas) on sulfate reduction and diffusive nutrient flux in the coastal sediments of Jinhae-Tongyeong, Korea. Marine Pollution Bulletin 74 (1): 187-198.

IPCC. 2007. Climate change 2007: The physical science basis. Contribution of working group I to the fourth assessment report of 
the intergovernmental panel on climate change, ed. S.D. Solomon, D. Qin, M. manning, Z. Chen, M. marquis, K.B. Averyt, M. Tignor, and H.L. miller, Cambridge-New York: Cambridge University press.

Jahan, R., and J.K. Choi. 2014. Climate regime shift and phytoplankton phenology in a macrotidal estuary: Long-term surveys in Gyeonggi Bay, Korea. Estuaries and Coasts 37: 1169-1187.

Jahan, R., H.C. Choi, Y.S. Park, Y.C. Park, J.H. Seo, and J.K. Choi. 2013. Implementation of self-organizing maps (SOM) to analyses of environmental parameters and phytoplankton biomass in a macrotidal estuary and artificial lake. Journal of the Marine Biological Association of the United Kingdom 93: 1-12.

Joo, H., J.W. Park, S. Son, J.-H. Noh, J.-Y. Jeong, J.H. Kwak, S. SauxPicart, J.H. Choi, C.-K. Kang, and S.H. Lee. 2014. Long-term annual primary production in the Ulleung Basin as a biological hot spot in the East/Japan Sea. Journal of Geophysical Research, Oceans 119: 3002-3011. https://doi.org/10.1002/2014JC009862.

Joo, H.T., S.H. Son, J.-W. Park, J.J. Kang, J-Y. Jeongc, J.-I. Kwon, C.-K. Kang, and S. H. Lee. 2017. Small phytoplankton contribution to the total primary production in the highly productive Ulleung Basin in the East/Japan Sea. Deep-Sea Research Part II 143: 54-61.

Jørgensen, B.B. 2006. Bacteria and marine biogeochemistry. In Marine geochemistry, ed. H.D. Schulz and M. Zabel, 169-206. Berlin: Springer.

Jung, H.K., S.M.M. Rahmanb, C.-K. Kang, S.-Y. Park, S.H. Lee, H.J. Park, H.-W. Kim, and C.I. Lee. 2017. The influence of climate regime shifts on the marine environment and ecosystems in the East Asian Marginal Seas and their mechanisms. Deep-Sea Research Part II 143: 110-120.

Kang, J.W. 1999. Changes in tidal characteristics as a result of the construction of sea-dike/sea-walls in the Mokpo coastal zone in Korea. Estuarine, Coastal and Shelf Science 48: 429-438.

Kim, J., and T.-H. Kim. 2018. Distribution of humic fluorescent dissolved organic matter in lake Shihwa: The role of the redox condition. Estuaries and Coasts https://doi.org/10.1007/s12237-018-00491-0.

Kim, J.B., J.-I. Park, C.-S. Jung, P.-Y. Lee, and K.-S. Lee. 2009. Distributional range extension of the seagrass Halophila nipponica into coastal waters off the Korean peninsula. Aquatic Botany 90: 269-272.

Kim, T.-W., K. Lee, R.G. Najjar, H.-D. Jeong, and H.J. Jeong. 2011. Increasing $\mathrm{N}$ abundance in the northwestern Pacific Ocean due to atmospheric nitrogen deposition. Science 334 (6055): 505-509.

Kim, S.H., Y.K. Kim, S.R. Park, and K.-S. Lee. 2012. Growth dynamics of the seagrass Halophila nipponica, recently discovered in temperate coastal waters of the Korean peninsula. Marine Biology 159: 255-267.

Kim, I.-N., K. Lee, N. Gruber, D.M. Karl, J.L. Bullister, S. Yang, and T.W. Kim. 2014a. Anthropogenic N deposition increasing anthropogenic nitrogen in the North Pacific Ocean. Science 346 (6213): 1102-1106.

Kim, J.-Y., D.-J. Kang, T. Lee, and K.-R. Kim. 2014b. Long-term trend of $\mathrm{CO}_{2}$ and ocean acidification in the surface water of the Ulleung Basin, the East/Japan Sea inferred from the underway observational data. Biogeosciences 11: 2443-2454.

Kim, Y.-S., Y.-H. Lee, J.-N. Kwon, and H.G. Choi. 2015. The effect of low oxygen conditions on biogeochemical cycling of nutrients in a shallow seasonally stratified bay in Southeast Korea (Jinhae Bay). Marine Pollution Bulletin 95 (1): 333-341. https://doi.org/10.1016/ j.marpolbul.2015.03.022.

Kim, B., A. Choi, K.-S. Lee, C.-K. Kang, and J.-H. Hyun. 2017a. Sulfate reduction and sulfur cycles at two seagrass beds inhabited by cold affinity Zostera marina and warm affinity Halophila nipponica in temperate coastal waters. Estuaries and Coasts 40: 1346-1357.

Kim, B., S.-H. Kim, J.H. Kwak, C.-K. Kang, S.H. Lee, and J.-H. Hyun. 2017b. Heterotrophic bacterial production, respiration, and growth efficiency associated with upwelling intensity in the Ulleung Basin, East Sea. Deep-Sea Research Part II 143: 24-35.

Kim, S.-H., J.S. Lee, and J.-H. Hyun. 2017c. Extremely high sulfate reduction, sediment oxygen demand and benthic nutrient flux associated with a large-scale artificial dyke and its implication to benthicpelagic coupling in the Yeongsan River estuary, Yellow Sea. Marine Pollution Bulletin 120 (1-2): 126-135. https://doi.org/10.1016/j. marpolbul.2017.04.047.

Kim, B., S.-U. An, T.-H. Kim, and J.-H. Hyun. 2019a. Uncoupling between heterotrophic bacteria and phytoplankton and changes in trophic balance associated with warming of seawater in Gyeonggi Bay, Yellow Sea. Estuaries and Coasts https://doi.org/10.1007/s12237019-00606-1.

Kim, C., H.Y. Kang, Y.-J. Lee, S.-G. Yun, and C.-K. Kang. 2019b. Isotopic variation of macroinvertebrates and their sources of organic matter along an estuarine gradient. Estuaries and Coasts https://doi. org/10.1007/s12237-019-00543-z.

Kim, M., L.-Z. Qin, S.H. Kim, H.-J. Song, Y.K. Kim, and K.-S. Lee. 2019c. Influence of water temperature anomalies on the growth of Zostera marina plants held under high and low irradiance levels. Estuaries and Coasts https://doi.org/10.1007/s12237-019-00578-2.

Kim, S.-H., H.C. Kim, S.-H. Choi, W.-C. Lee, R.-H. Jung, J.-H. Hyun, S.H. Kim, and J.S. Lee. 2019d. Benthic respiration and nutrient release associated with net cage fish and longline oyster aquaculture in the Geoje-Tongyeong coastal waters in Korea. Estuaries and Coasts https://doi.org/10.1007/s12237-019-00567-5.

Kirwan, M.L., and J.P. Megonigal. 2013. Tidal wetland stability in the face of human impacts and sea-level rise. Nature 504: 53-60.

KORDI. 2010. Korea Ocean Research and Development Institute. A pilot study on predicting long-term ecosystem changes in the East Sea. BSPE 98442-2249-3. P.212.

KOSIS. 2018. Korean statistical information service. http://kosis.kr/ statHtml/statHtml.do? orgId=101\&tblId=DT 1EW0001\&vw. Accessed 2 January 2018.

Kuo, J., Z. Kanamoto, H. Iizumi, K. Aio, and H. Mukai. 2006. Seagrasses of the genus Halophila Thouars (Hydrocharitaceae) from Japan. Acta Phytotaxonomica Geobotanica 57: 129-154.

Kwak, M.-T., and Y.-K. Cho. 2019. Seasonal variation in residence time of two neighboring bays with contrasting topography. Estuaries and Coasts https://doi.org/10.1007/s12237-019-00644-9.

Kwon, H.K., J. Seo, H.-M. Cho, and G. Kim. 2018. Tracing different freshwater sources for nutrients and dissolved organic matter in coastal waters off Jeju island using radon. Estuaries and Coasts https://doi.org/10.1007/s12237-018-0471-y.

Lee, M.-O., and J.-K. Kim. 2008. Characteristics of algal blooms in the southern coastal waters of Korea. Marine Environmental Research 65 (2): 128-147. https://doi.org/10.1016/j.marenvres.2007.09.006.

Lee, K.-S., and S.Y. Lee. 2003. The seagrasses of the republic of Korea. In World atlas of seagrasses: Present status and future conservation, ed. E.P. Green and F.T. Short, 193-198. California: University of California Press.

Lee, K.-S., S.R. Park, and J.-B. Kim. 2005. Production dynamics of the eelgrass, Zostera marina in two bay systems on the south coast of the Korean peninsula. Marine Biology 147: 1091-1108.

Lee, C.K., T.G. Park, Y.T. Park, and W.A. Lim. 2013. Monitoring and trends in harmful algal blooms and red tides in Korean coastal waters, with emphasis on Cochlodinium polykrikoides. Harmful Algae 30: $\mathrm{S} 3-\mathrm{S} 14$

Lee, S.H., S. Son, H.-U. Dahms, J.W. Park, J-H. Lim, J.-H., Noh, J.-I. Kwon, H. Joo, J.Y. Jeong, and C.-K. Kang. 2014. Decadal changes of phytoplankton Chl-a in the East Sea/Sea of Japan. Oceanology 6: 771-779.

Lee, S.H., C.-K. Kang, C.I. Lee, and J.H. Kwak. 2017. Current status of the East/Japan Sea ecosystem in a changing world. Deep-Sea Research II 143: 120 pp. 
Lee, J., K.-T. Park, J.-H. Lim, J.-E. Yoon, and I.-N. Kim. 2018. Hypoxia in Korean coastal waters: A case study of the natural Jinhae bay and artificial Shihwa bay. Frontiers in Marine Science 5: 70. https://doi. org/10.3389/fmars.2018.00070.

Legendre, L., and J. Le Fèvre. 1995. Microbial food webs and the export of biogenic carbon in oceans. Aquatic Microbial Ecology 9: 69-77.

Li, J., L. Pu, M. Zhu, J. Zhang, P. Li, X. Dai, Y. Xu, and L. Liu. 2014. Evolution of soil properties following reclamation in coastal areas: A review. Geoderma 226-227: 130-139.

Lim, D.-I., H.S. Jung, K.T. Kim, H.H. Shin, and S.W. Jung. 2012. Sedimentary records of metal contamination and eutrophication in Jinhae-Masan Bay, Korea. Marine Pollution Bulletin 64 (11): 2542 2548. https://doi.org/10.1016/j.marpolbul.2012.07.033.

Middelburg, J.J., and L.A. Levin. 2009. Coastal hypoxia and sediment biogeochemistry. Biogeosciences 6: 1273-1293.

Mok, J.-S., S.-H. Kim, J. Kim, H. Cho, S.-U. An, A. Choi, B. Kim, C. Yoon, B. Thamdrup, and J.-H. Hyun. 2019. Impacts of typhooninduced heavy rainfalls and resultant freshwater runoff on the partitioning of organic carbon oxidation and nutrient dynamics in the intertidal sediments of the Han River estuary, Yellow Sea. Science of Total Environment 691: 858-867.

Murray, N.J., R.S. Clemens, S.R. Phinn, H.P. Possingham, and R.A. Fuller. 2014. Tracking the rapid loss of tidal wetlands in the Yellow Sea. Frontiers in Ecology and the Environment 12: 267272.

Neubauer, S.C., and J.T. Verhoeven. 2019. Wetland effects on global climate: Mechanisms, impacts, and management recommendations. In Wetlands: Ecosystem Services, Restoration and Wise Use, 39-62. Dordrecht, Netherlands: Springer.

Park, H.J., Y.-J. Lee, E. Han, K.-S. Choi, J.H. Kwak, E.J. Choy, and C.-K. Kang. 2019a. Effect of the Hebei Spirit oil spill on the condition, reproduction, and energy storage cycle of the manila clam Ruditapes philippinarum on the west coast of Korea. Estuaries and Coasts https://doi.org/10.1007/s12237-019-00529-x.

Park, H.J., J.H. Kwak, Y.-J. Lee, H.Y. Kang, E.J. Choy, and C.-K. Kang. 2019b. Trophic structures of two contrasting estuarine ecosystems with and without a dike on the temperate coast of Korea as determined by stable isotopes. Estuaries and Coasts https://doi.org/10. 1007/s12237-019-00522-4.

Park, J.-E., K.-A. Park, C.-K. Kang, and G. Kim. 2019c. Satelliteobserved chlorophyll-a concentration variability and its relation to physical environmental changes in the East Sea (Japan Sea) from 2003 to 2015. Estuaries and Coasts https://doi.org/10.1007/s12237019-00671-6.

Park, J.-E., K.-A. Park, C.-K. Kang, and Y.-J. Park. 2019d. Short-term response of chlorophyll-a concentration to change in sea surface wind field over mesoscale eddy. Estuaries and Coasts https://doi. org/10.1007/s12237-019-00643-w.
Park, J.-S., S. Keshavmurthy, T. Subramaniam, S.-R. Park, C.-K. Kang, and K.-S. Choi. 2019e. Annual gametogenesis patterns in two highlatitude corals, Alveopora japonica and Oulastrea crispata, from Jeju island, South Korea. Estuaries and Coasts https://doi.org/10. 1007/s12237-019-00539-9.

Park, T.H., C.-I. Lee, C.-K. Kang, J.H. Kwak, S.H. Lee, and H.J. Park. 2019f. Seasonal variation in food web structure and fish community composition in the East/Japan Sea. Estuaries and Coasts https://doi. org/10.1007/s12237-019-00530-4.

Qin, L.Z., S.H. Kim, H.-J. Song, Z. Suonan, H. Kim, O. Kwon, and K.-S. Lee. 2019. Influence of regional water temperature variability on the flowering phenology and sexual reproduction of the seagrass Zostera marina in Korean coastal waters. Estuaries and Coasts https://doi.org/10.1007/s12237-019-00569-3.

Rabalais, N., R. Diaz, L. Levin, R. Turner, D. Gilbert, and J. Zhang. 2010. Dynamics and distribution of natural and human-caused hypoxia. Biogeosciences 7: 585-619. https://doi.org/10.5194/bg-7-585-2010.

Sarmiento, J.L., T.M.C. Hughes, R.J. Stouffer, and S. Manabe. 1998. Simulated response of the ocean carbon cycle to anthropogenic climate warming. Nature 393: 245-249.

Shin, H.H., L. Zhun, Y.H., Yang, S.J. Oh, and W.-A. Lim. 2017. Formation and germination of temporary cysts of Cochlodinium polykrikoides Margalef (Dinophyceae) and their ecological role in dense blooms. Harmful Algae 66: 57-64.

Siegel, D.A., K.O. Buesseler, S.C. Doney, S.F. Sailley, M.J. Behrenfeld, and P.W. Boyd. 2014. Global assessment of ocean carbon export by combining satellite observations and food-web models. Global Biogeochemical Cycles 28: 181-196.

Sin, Y., B. Hyun, B. Jeong, and H.Y. Soh. 2013. Impacts of eutrophic freshwater inputs on water quality and phytoplankton size structure in a temperate estuary altered by a sea dike. Marine Environmental Research 85: 54-63.

Sin, Y., E. Lee, Y. Lee, and K.-H. Shin. 2015. The river-estuary continuum of nutrients and phytoplankton communities in an estuary physically divided by a sea dike. Estuarine Coastal and Shelf Science 163: 279-289.

Sin, Y., and B. Jeong. 2019. Anthropogenic disturbance of tidal variation in the water properties and phytoplankton community of an estuarine system. Estuaries and Coasts https://doi.org/10.1007/s12237019-00557-7.

Winder, M., and U. Sommer. 2012. Phytoplankton response to a changing climate. Hydrobiologia 698: 5-16.

Yim, J., B.-O. Kwon, J. Nam, J.H. Hwang, K. Choi, and J.S. Khim. 2018. Analysis of forty years long changes in coastal land use and land cover of the Yellow Sea: The gains or losses in ecosystem services. Environmental Pollution 241: 74-84.

Yoo, S., and J. Park. 2009. Why is the southwest the most productive region of the East Sea/Sea of Japan? Journal of Marine Systems 78: 301-315. 